\title{
Currency Systems and Their Role in Entering and Leaving the Economic Crisis*
}

\author{
Jakub Jedlinský \\ University of Economics in Prague, Prague, the Czech Republic
}

\begin{abstract}
The paper focuses on a comparison of two contrasting approaches: having a single universal currency in a given fiscal area or supporting a concurrent presence of more competing currencies of different types. A systemic analysis (based on studying both conventional and unorthodox literature) of the modern monetary system points out that the very type of money that is used suffers internal errors that make a crisis inevitable. The indebtedness is systemic and unavoidable in a currency that is issued as a liability. Parallel currencies are proposed as a general solution. A specific solution, including a redefined national currency, is offered too, with an outline of its possible experimental verification. Such a system could help to prevent the next economic crisis, mitigate it, or at least facilitate its leaving. The paper also deals with criticism that is held against the idea of concurrent currencies.
\end{abstract}

Keywords: redefinition of money, Gresham's law, Tinbergen's rule, economic crisis

\section{Introduction}

The Austrian school of economics sees the economic cycle with its booms and busts (crises) as a monetary issue caused by fractional reserve banking (Mises, 1998; Soto, 2012). The proposed solution is seen in a return to full reserve system and gold standard. Minsky's financial instability hypothesis (1992) describes a similar problem. The cycle is boosted by the behavior of economic agents. This paper gives credit to these theories but finds the problem to be deeper, embedded in the very foundations of the currency. The gold standard has its own issues that will be discussed. It leads to another kind of instability. Any kind of regulation can possibly mitigate the problems connected to over-indebtedness but cannot prevent the accumulation of debt in the economy either.

The aim of this paper is to prove that the crisis experienced in 2008 was caused by a wrongly defined currency. The main hypothesis goes like this: The current monetary system does not perform desired functions of money satisfactorily. It prevents the economy from reaching its true potential and widens the gaps among particular economic agents. What is more, it enables the phenomena described by Minsky (1992) and the Austrians.

The secondary aim of the paper is to support the opinion that a sustainable solution lays in the creation of such a monetary system that would be flexible. Such flexibility can only be achieved when more concurrent

\footnotetext{
* Acknowledgement: This research was financially supported within a grant (IGA VŠE) —IG210014—Nové směry governance ve světle finanční a dluhové krize.

Jakub Jedlinský, Mgr., Ing., Department of World Economy, University of Economics in Prague, Prague, the Czech Republic.

Correspondence concerning this article should be addressed to Jakub Jedlinský, Sokolovská 124, Prague 18600, the Czech Republic. E-mail: jjedlinsky@gmail.com.
} 
currencies operate in a market that are designed to specialize for performing certain monetary functions only. Theorems like Gresham's law and Tinbergen's rule will be used in order to prove the hypothesis.

A systemic analysis will be carried out in order to identify the internal errors in the modern currency. A heterodox approach will be used for the studying of the related literature. A necessity of an emergence of a crisis will be deducted from these errors. A specific multi-currency monetary setting will be designed that resonates with the discovered findings and does not suffer the same errors. A possible experimental verification will be outlined to test the setting.

\section{Literature Review}

The neoclassical economics basically operates in terms of real economy and oversees the substantial role of money as was described by Keen (2011), Hudson, Innes, and Wray (2004), or Borio (Klein, 2012). Some alternative schools like the Austrian ones or Postkeynesians give regard to credit, though.

According to Minsky (1992), over a protracted period of good times, capitalist economies tend to move from a financial structure dominated by hedge finance units to a structure in which there is large weight to units engaged in speculative and Ponzi finance. The instability rises from the emergence of excessive credit that is taken by market agents in order to speculate or inflate Ponzi bubbles. When a regulator decides to step in and taper the schemes, Fisher's debt deflation (1933) may occur, freezing the liquidity in the market, effectively making any investment impossible.

The Austrian story (Soto, 2012) begins with a central bank setting interest rates below the hypothetical market price. New money is borrowed into the economy as credit and spent in areas which would normally be financed less. Bubbles are inflated again, only to burst when people realize that there was not enough underlying value.

Both theories identify the excessive credit as a cause of the instability, cycle, and crises. Both claim that a crisis does not have to be triggered by an external shock. The financial instability hypothesis is a model of a capitalist economy which does not rely upon exogenous shocks to generate business cycles of varying severity (Minsky, 1992). This paper accepts that the business cycle is not exogenous (as the biblical seven years of hunger) and studies the question whether it is possible to have a credit based fiat currency and not to inflate the economy with credit at the same time.

Is it possible to issue new units of money without adding more debt into the economy? The usual way new money flows into a modern economy was described in a report published by Bank of England (McLeay, 2014). A commercial bank expands its balance by newly created accounting money on the liabilities side and an asset against it. The asset is typically a claim against a debtor who has taken credit from the bank, e.g., a mortgage. But it may also be a bond or even a non-financial asset, anything the bank buys with the money that has not existed before. As the debtor redeems his/her debt to the bank, the money is being cancelled, too. That is the way double-entry bookkeeping works. Every unit of money that is collateralized by debt has a termination moment. Every such unit is only temporary. So is there another way to issue money in the system?

According to Krejčí (1998), cash can be observed as money that is not being terminated, because it has physical representation that cannot be simply cancelled in an accounting way. Nevertheless, cash is issued by a central bank to replace electronic (giro) money. When electronic money is replaced by the new cash, it is terminated but the debt that arose with it is not. The debt thus stays in balances, making cash more of just a form of credit based money than an independent type that could be seen as non-liability. It is thus impossible 
for the money issuer (a commercial bank) to redeem such debt with cash, unless the cash is treasured and frozen. Krejčí (1998) implied that new money can be created, when a central bank performs open market operations. Such money is collateralized by foreign money, not debt. That is correct when author only considers a single national economy. From a global perspective, new money entered an economy, while other currency was withdrawn. Due to the possible change in mutual exchange rate, the total market capitalization of both currencies can rise but the effect is unsure, especially under the conditions of perfect competition. Mayer (2014), a proponent of vollgeld/positive money, believed that the only non-liability money is memorial coin. Also, governments of certain states are allowed to get new cash directly from the central bank and they only pay the costs of minting and printing. This issue, however, is systemically irrelevant.

The other question is whether it is possible to have growing economy without issuing new money. According to Fisher's equation (1933) of exchange, such growth would have to be achieved by either increasing velocity of money or deflation. Deflation causes perhaps even greater instability to a monetary economy than inflation does.

This paper sees a solution in a system consisting of multiple parallel currencies, whereby at least some of them would not be issued against debt. The idea of concurrent currencies was discussed and advocated in Hayek's denationalization of money (1976). He said that private currencies issued by commercial banks would compete with each other. The market would then find the best currency to become dominant in the monetary area. For Hayek (1976), as a representative of Austrian school of economics, the best currency would be the one having value which value would increase in time. It would be the best store of value. Inflationary currencies would not be demanded and used. Frisby (Keiser, 2013a) developed the idea and suggested that every subject should be allowed to issue a private currency, not only banks. Both promoters of free banking propose parallel currencies mainly as an instrument to find a single universal currency that would best fit the needs of a market.

Other economists favor a multi-currency system, because it enables the currencies to specialize for performing certain functions of money only. An example can be Suntum's concept (2013) of hard-euro and soft-euro. This idea is designed to resolve debt issues in the European Union without the need to abandon the project of a common currency for all the countries. Parallel currencies are discussed and used in praxis in order to scale the market in certain ways. There are two types of peso in Cuba. There was a parallel currency called Bony obtainable for foreign currency in socialist Czechoslovakia. It served for buying exclusive luxuries. Ecuador issues new digital currency as a medium of exchange so that the US dollar ${ }^{1}$ can be used for redeeming the sovereign debt (Mathew, 2014). Greece discusses the possibility of issuing parallel currencies for similar reasons (Bossone \& Cattaneo, 2015). Greece's Minister of Finance Varoufakis (2012) used to be an in-game economist. In-game virtual economies often use two or more currencies in order to address different issues and to stabilize the economy. Other important proponents of regional or parallel currencies are Thomas Jefferson, Bernard Lietaer, or Silvio Gesell (Cohen-Mitchell, 1998).

Some of the monetary functions are contradictory. Examples of theorems that explain trade-offs in using a single currency are Gresham's law and Triffin dilemma. The importance of this study lays in the fact that it follows this perspective but recognizes more monetary functions than the several ones which are commonly discussed in economics textbooks. It argues that trade-offs in currency settings are more of a general issue.

\footnotetext{
1 The US dollar has been a national currency in Ecuador since 2000.
} 
Other functions of money, including non-economic functions, were explained in the work by Graeber (2011) and in works of other anthropologists and economists, like Hudson et al. (2004).

\section{Definition of a Currency and Its Functions}

In the broadest sense, money is a mathematical expression of value. It is a psychological tool used while doing economic calculations. Being capable of doing this, money can perform various consequent functions. Acting as a medium of exchange is referred to as the most basic function; Samuelson (2010) described money this way in his popular textbook. Money also serves as a store of value and an accounting unit. Beside these, money also perform at least 15 other functions that are not often mentioned-some of them are economic and some are social.

Not every currency is used for all the functions. The European (or Western in general) monetary system is, however, based on the premise that there should be only one type of currency that shall join all of the possible functions within itself. People usually picture several national currencies when speaking about currencies in plural. Nevertheless, Euro, US dollar, and Czech crown are principally the same type of currency; the only difference is the geographical authority that gives patronage. The capability of these currencies to comply with the desired functions is very similar.

The economic theory often recognizes only the two main functions-medium of exchange and store of value - plus measure of value (informational function) and sometimes even standard of deferred payments. The reality is different. Over time, currencies were gaining more and more functions that could be distinguished. The other functions may be: ${ }^{2}$

- informational - how much costs what; a denominator of value; and what is it profitable to invest in;

- allocative-pairing of savings and investments; money flows to hands that can use them in the most profitable way;

- unit of account - the unit you denominate other things in when doing accounting;

- clearing unit - unit of account used for offsetting mutual debts;

- standard of deferred payment - money that is accepted as an instrument for settling debts;

- statutory-virtual penis; declaration of success; score (related to the concept of positional arms race); and measure of control over the others;

- social: $^{3}$ a manifestation of a social relation between the original and the new owner of the thing (money), e.g., tribute; members' allowances: to some extend taxation, a secondary phenomenon confirming the modification of the social relationship between the original and the new owner of the thing (money), e.g., dowry;

- wergeld - fine; compensation; and retribution;

- power-related to the authority standing behind the currency; increasing the power of the monetary monopoly;

- stabilizing - anchor for other currencies;

- world reserve currency — enabling international trade;

- investment — using money as an asset; making money out of money; and speculation;

\footnotetext{
${ }^{2}$ It is a non-exhaustive list.

3 According to the anthropologist David Graeber, the original functions of money were not commercial but statutory and social. The very basic quality of money is its power to depersonalize social relations.
} 
- redistributive - government transfers; taxes; moving wealth from lower levels of the economy to the upper or vice versa;

- stimulant of desirable behavior-ecological permits; generally tokens related to externalities; and food stamps to some extend;

- money laundering - breaking the link between a (criminal) activity and its outcome (profit); connected to the depersonalization that money does.

The currency that most commonly used is a credit-based fiat currency. Any currency can be defined by its substance (physical, arbitrary, and electronic protocol), carrier (e.g., a bank note or bullion), monetary unit, transmission system, institutions, collateral (an asset or commodity the currency is collateralized by), creation and termination, and monetary authority.

The substance of credit fiat is purely arbitrary (McLeay, 2014). Money is kept on an account of a financial institution that is entitled to record and claim that someone's money is in a certain place. Digital money is nothing more than a record of debt backed by an authority. The substance of credit fiat is double-entry bookkeeping.

The carrier of credit fiat is sometimes cash, but mostly just the accounting record. Securities may also be viewed as money. A monetary unit is the basis for calculations. One euro is a similar concept to one kilogram or one Newton. Usually, it overlaps with the name of the currency (renminbi and yuan being an example of an exception).

The transmission system is provided by banks, payment systems like Western Union or PayPal, and basically by accounting. Financial institutions that are empowered to create new money by credit and to keep the records of money flows are also the most important institutions, second to central banks only. Nowadays, the capacity of commercial banks to influence the money supply is sometimes considered superior to that of central banks, according to the theory of endogenous money (Krejčí, 1998). Stock exchanges and legislative political authorities belong to other important institutions.

Modern fiat money is not collateralized by any physical asset but by the performance of a national economy. That is an empty political claim with no real content. The only tangible connection to real economy is the duty to pay taxes in fiat.

Money is created as an accounting record, when someone takes a credit or sells a bond. A corresponding debt is created, too. It is not possible to create anything against nothing in the double-entry bookkeeping, that is why there always must be a corresponding debt against new money. The money is also erased, when the credit is repaid. Equity securities or derivatives can also be considered money. They are created by simple pricing through accepting their price. Unlike debt securities, they are illiquid and cannot be simply erased in order to cancel a debt.

The monetary authority is supposedly the state, but it only has a little control over money. The institutions mentioned above are actually in control. The state creates a legal framework and promotes its currency as a legal tender. The state guarantees the trust in the currency and in its value. Murphy (2013) said that fiat money is backed by the fact that you pay taxes in it. Fiat money is backed by men with guns. Bitcoin is not, so why should it have any value?

\section{Role of Credit Based Fiat Currency in Entering the Crisis}

According to Borio (Klein, 2012), Keiser (2013b), Clauss (2009), Keen (2011), Aziz (2013), Dalio (2012), 
and Cervenka (2012), a credit based fiat currency is experiencing a systemic and global crisis. Ever since the system was introduced in the 70's, it has been dominating the world for more than 40 years. That is significantly longer than the previous Bretton woods system or most systems in centuries before.

In the beginning of the 70's, the USA represented by President Nixon technically defaulted on their liabilities and broke away from the gold standard. Many argue today that leaving the gold standard was a mistake and that such a system could work. The system surely can work, but it is questionable whether it can work no matter what the circumstances are and no matter what the time is.

There are at least two significant disadvantages related to the gold standard. Firstly, the monetary system responds poorly to a rapid change in the scarcity of gold. That strongly damaged the Spanish economy when ships with bullion started to return from Americas. Secondly, the system is not flexible enough. With booming economy and increase in production, more transactions happen. That — ceteris paribus-leads to an increased demand (or need) for money. No matter the money is metal coins or paper collateralized by metal, it leads to reduction of the amount of metal attributable to a unit of money. ${ }^{4}$ That is dangerous, because the value of the currency is based on the trust in the value of the collateral. The collateral remains unchanged but must support more money and logically, the trust in the money decreases. A further negative side effect is that population tries to keep its savings directly in the underlying asset. That leads to shrinkage of gold reserves, auto-catalytically, in a spiral. The real value of the currency thus decreases, not only due to nominal inflation, but also due to thinning of the reserve of collateral.

Bitcoin, for instance, has the same problem. Its amount does not reflect the true needs of an economy in any way. It does not matter, because it takes over the pricing from dominant currencies in particular states, but should it once become a dominant currency itself, it would be impractical. Leaving the gold standard was not a one-time issue forced by unpredictable circumstances. Banknotes became legal tender long time ago. During the 20th century, the right to exchange banknotes for gold was restricted and left only for states. Later, only USD was directly pegged to gold, while other currencies did so only through USD. Still, there was a link between currency and value. The link was getting weaker since 1913, when convertibility of USD to gold fell from $100 \%$ to $40 \%$ for the first time. Credit fiat has no link to value any longer. That is why it is a separate type of money.

This paper assumes that the suitability of the same currency for performing various functions of money may be different in the beginning of its existence and at its end. This is caused by several factors: the inner error that is present in every system; awareness about the currency and number of its "users"; and also the market capitalization of the currency, which is the sum of its units expressed in a relation to another currency.

A system is an organized purposeful structure that consists of interrelated and interdependent elements (components, entities, factors, members, parts, etc.). These elements continually influence one another (directly or indirectly) to maintain their activity and the existence of the system, in order to achieve the goal of the system (WebFinance Inc, 2014). Every system is under the influence of entropy, which leads to a gradual meltdown. Every system evolves with time, either due to its internal tensions or due to external circumstances it must react to. There is, however, a tendency to return to a homeostatic balance in every system. In case the paradigm changes fundamentally — the homeostatic point in this case, a new system can be discussed.

This paper assumes that no system is sustainable in the long run. There has been none to rebut the

\footnotetext{
${ }^{4}$ The other option is deflation.
} 
assumption. The error seems to be tiny and insignificant considering the benefits of the system. The error grows in importance with time. One day, there comes a critical moment when the costs of the inner error overgrow the benefits of the system. Then it is rational to change the paradigm. Fukuyama (1992) wrote the same in "The End of History and the Last Man", when commenting on political systems. The value of an idea stands in its falsifiability. The better a system is, the easier it will be replaced when found wrong. Searching for an ideal system is like trying to reveal God's mystery. This paper keeps revealing more and more layers of errors getting closer to the goal, yet the goal cannot be reached.

It was rational and useful to leave the Bretton woods system that was already failing in the beginning of the 70's. Economies needed a currency that would flexibly respond to the market needs. The inner error-debt integrated into the currencies' substance - had a negligible importance. It was a favorable trade-off for growth. From a certain point of view, it was even a protection against overheating of the economy, against inflation, wasting, etc. But the global systemic debt has been growing fast since then. Today, it paralyzes a notable portion of Western economies.

The concept of euro was created in the 60's, which is before abandoning the Bretton woods system and before the information revolution. It has not evolved by definition since then, it had to adapt to the absence of gold anchor only. It pulled needed money to the growing economy via credit. The system offered no possibility to diminish the amount of debt without diminishing the amount of money at the same time.

The "miracles" performed by credit are fundamentally comparable to the "miracles" an association of counterfeiters could perform for its benefit by lending its forged banknotes in return for interest. In both cases, the stimulus to the economy would be the same and the only difference is who benefits (Phillips, 1992). Czech economists discussed the topic from theoretical points of view, including the Austrian perspective:

The view of the creation of credit, its dynamics, and relation to deposits differs between Postkeynesians and Austrians. The Postkeynesians emphasize the relative freedom of commercial banks to provide credit, for a provided credit to a firm of household on the asset side of bank's balance automatically creates sources on the liabilities side, usually by a current deposit of the client. The Austrian school, on the other hand, binds a healthy credit to a previous acceptance of a term deposit from the client. Austrians also demand $100 \%$ reserve requirements in case of a current deposit. It may appear for Postkeynesians that bank deposit policy is senseless; due to the motto "We will create our own sources". For Austrians, marketing and management on the field of deposits are crucial for a commercial bank. A much faster growth in credit loaning than in GDP will always end up with over-indebtedness of partial subjects, resp. sectors in national economy. ${ }^{5}$ (Mandel \& Tomšík, 2015, p. 1)

Their empirical research (a correlation analysis and Granger causality test) proved that there was no relationship between the change in terms of deposits and change of credits provided to non-financial businesses in the Czech Republic in years from 2000 to 2013.

The credit-based fiat currency uncouples investment from savings. That denies the very essence of capitalism. The error used to be more or less hidden behind the benefits of expanding economy for decades.

\footnotetext{
${ }^{5}$ It is the liberal unautorized translation of "Pohled na vznik úvěru, jeho dynamiku a vztah k depozitům je zcela odlišný u 'ortodoxních' postkeynesovců a u představitelů rakouské školy. Postkeynesovci zdůrazňují relativní volnost obchodních bank při poskytování úvěrů, nebot' poskytnutí úvěru podniku nebo domácnosti na straně bankovních aktiv z účetního pohledu automaticky vytváŕí zdroje na straně pasiv zpravidla ve formě běžného depozita klienta. Rakouská škola naopak vznik zdravého úvěru váže na předchozí přijmutí termínovaného depozita od klienta. Zároveň požaduje $100 \%$ povinné rezervy bank $\mathrm{v}$ př́ípadě přijmutí běžného depozita. $\mathrm{V}$ př́ípadě postkeynesovců se může zdát, že bankovní depozitní politika je zbytečná pod heslem 'zdroje si vytvoříme sami'. Z pohledu rakouské školy je naopak marketing a management v oblasti depozit pro obchodní banky klíčový. Výrazně rychlejší růst úvěru než HDP nakonec vždy končí předlužením jednotlivých subjektů, resp. sektorů v národním hospodářství".
} 
Before the crisis, the systemic indebtedness had reached a level, when common monetary policies appeared to be non-functioning. "Monetary policy typically operates by encouraging borrowing, boosting asset prices and risk-taking. But initial conditions already include too much debt, too-high asset prices (property), and too much risk-taking" (Klein, 2012, p. 5). In order to keep the circus going and in an attempt to avoid the Japanese scenario, Western central bankers supported creating bubbles (dot-com bubble, real estate bubbles, and derivatives bubbles). Stock markets kept skyrocketing and everybody could feel prosperous.

In 2008, it was no longer possible to conceal the systemic fraud. The gigantic financial leverage broke, Lehman brothers fell, several systemic institutions were nationalized and stock-markets fell. Fisher's debt-deflation theory (1933) proved itself true again.

European economies have tried to cure the financial problems by converting over-indebtedness of partial sectors into states' balance sheets and then lowering this debt with austerity measures. People learned a lesson from this attempt. It is impossible to lower the debt-to-gross domestic product (GDP) ratio in a system where money (and consequently the economy's outcome) is strongly correlated to debt by using restrictive monetary policy (Jedlinský, 2014a). It took long years for the leaders to find out that it is equally hopeless as in Argentina (Eichengreen, 2013). They have changed the strategy recently and tried to mask the indebtedness by cooking the books.

There are two ways on how to improve the debt-to-GDP ratio, either to report a higher GDP or to report less debt. The GDP may be expanded by including items that traditionally do not enter it. The debt may be hidden in other balance sheets. (Jedlinský, 2014a, p. 7)

In 2014, European countries started counting black market activities in GDP. It makes the ratio lower. Some economists speculate that Europe will have to default on its debts anyway.

The USA tried a different strategy, when they pushed tremendous amounts of new money into the economy using quantitative easing. The US economy seems to be in a better shape than the European now because they did not undergo the counterproductive austerity measures. Still, the idea that the county would grow out of debt appears to be equally foolish. They have already encountered the liquidity trap. The interest rates are negative in real terms, even though the data concerning inflation are often being rigged. Newly issued money does not enter the real economy, because of the risk and something Keiser (2013b) called interest rate apartheid wall, but only push the bubbles on financial and real estate markets.

The crisis was a clear signal that people should change the currency. The leaders did all they could to save the currency (and the banks) regardless of the great costs. Many people though started to see the problem in the currency and financial system used and started to seek for alternatives:

- BRICS countries (Brazil, Russia, India, and China) are working on a project of their own reserve currency and investment bank;

- China, Russia, and Japan have been preparing contracts for trade denominated and carried out in their national currencies;

- There have been many protests in the streets. There was more or less a revolution in Iceland;

- Anti-systemic political parties and movements are gaining popularity;

- Germany has made a lot of effort to get its monetary gold reserves from New York and Paris back to Frankfurt since 2012. Russia has started issuing bonds collateralized by gold. ISIS plans to issue its own gold-backed currency; 
- Bitcoin and other new cryptocurrencies have become extremely popular, especially after the financial crisis in Cyprus.

Hayek (1976) suggested abandoning the monetary monopoly in the 70's already. He would allow commercial banks to emit private money. In his world, each bank would print its own currency, not a single common one.

It is, however, clearly not practicable to allow tokens with the same name and readily exchangeable against each other to be issued competitively, since nobody would be in a position to control their quantity and therefore be responsible for their value. (Hayek, 1976, p. 56)

The quote looks a little bit funny and confusing from today's perspective, because he basically defined the financial system of credit based fiat currency that people live in and that already existed in the time he wrote these words (the book was first published in 1976). It is clear from the whole book that Hayek (1976) was not able to foresee the dimensions that a credit issuance of money by commercial banks would eventually reach. He treated this money as a small deviation from the norm rather than a systemic matter. In his times, most of the countries operated on the system of currency board or fixed exchange rate with a fluctuation band.

\section{Role of Credit Based Fiat Currency in Leaving the Crisis}

The first issue is a liquidity trap. The interest rates are so low that they cause a liquidity trap. Printing new money (by Europeanization of debt) does not lead to its allocation in the real economy.

There is, therefore, a longer-term structural problem with monetary policy. As the Bank for International Settlements noted, Policy does not lean against the booms but eases aggressively and persistently during busts (Retrieved from http://www.bis.org/publ/arpdf/ar2014e.htm). This induces a downward bias in interest rates and an upward bias in debt levels, which in turn makes it hard to raise rates without damaging the economy-a debt trap. Systemic financial crises do not become less frequent or intense, private and public debts continue to grow, the economy fails to climb onto a stronger sustainable path, and monetary and fiscal policies run out of ammunition (Retrieved from http://www.bis.org/publ/arpdf/ar2014e.htm). Classical instruments do not perform their roles. The booming credit boosts the amount of debt but not the GDP, because the velocity of money continually decreases (Jílek, 2013).

The insufficient purchasing power caused by the fiat currency affected by liquidity trap gave an impulse for creating many alternative currencies: local currencies, voucher-currencies, virtual currencies, and, last but not least, cryptocurrencies. The same pattern was applied in the 1930s. Thousands of local currencies appeared in reaction to the Great Depression (Keiser, 2013c). The study of local currencies in the first half of 20th century was conducted by Gesell (1916), a proponent of demurrage.

Another issue is over-indebtedness. The economy is too indebted. Such a situation prevents it from conducting energetic and courageous steps and exposes it to attacks from speculators, hedge funds, etc. The global complete over-indebtedness seems absurd. It is only possible for two reasons. Firstly, major economic agents seldom clear their mutual debts. If Germany owes 100 billion to Italy and Italy owes 100 billion to Germany, the debt is counted as 200 billion, not zero. Secondly, a substantial portion of the debt is not owed to subjects/creditors but to banks' balance sheets. It is the debt that, in the double-entry bookkeeping system, allows banks to create money out of thin air. The final creditor in this system (often referred to as endogenous money) is virtual. The creditor is an impersonal accounting record - a sheet of paper. There is no one's claim 
against these initial "debts". Still people treat the debtors as sinners and inhibit their own economic activity because of this artificial debt.

As pointed out before, the debt can never be repaid.

To date, the US and the UK have done a good job of managing the trade-off between deleveraging policies and output costs. They did this by avoiding credit crunches while still achieving meaningful debt reductions in their private sectors and their financial systems. This result, however, was achieved at the cost of a substantial re-leveraging of the public sector-including their central banks. As a consequence, deleveraging the central banks will be a primary policy challenge for the foreseeable future. (Buttiglione, Lane, Reichlin, \& Reinhart, 2014, p. 1)

Europeans hope to reach the $60 \%$ stability and growth pact debt-to-GDP criterion in decades.

The Austrian school is correct in requiring $100 \%$ reserves. But such a thing is impossible in a system where a parasitic (or fiduciary) issuance of money cannot be distinguished from a primary issuance (in fact, there is nothing like a primary issuance at all. Money created by central banks is also a derivative of debt securities). Ipso facto, every debt creates new money.

That is why there is a need to separate "hard" money from the credit issuance. It must be a different instrument. It must be recorded separately, so that the debt gives a correct signal. People are fully dependent on bookkeeping today. Money is only an accounting record. Cooking the books is the easiest thing ever. People need to have not-accounting money whose creation and termination would be recorded by accounting, not performed by it. The Austrian call for $100 \%$ reserves seems to be in a contradiction to parallel currencies. A parallel currency can play a role of a fiduciary instrument to the main currency, thus bypassing the $100 \%$ reserves requirement. This inconsistence is merely apparent, however, each such fiduciary issue would be clearly distinguishable from the main (hard) currency. Instability in a parallel currency does not have to harm the stability of the main currency. Nevertheless, the main currency acts as an anchor in the system (just like gold used to do in the system of free coinage gold standard).

A credit based currency is utterly unusable for repaying the initial debt. It would fully disappear, should it redeem it. The effort to solve this systematically unsolvable problem leads to constant pushing of banks' balance sheets and to a threat of their implosion.

Last but not least, there is a productivity trap. Besides these relatively virtual, monetary issues, the economy experiences a productivity trap. The productivity trap is caused by a rampant growth in work efficiency achieved thanks to the information revolution and not followed with a similar revolution in finance. This is a physical problem, directly affecting the real economy. The potential product rises, while purchasing power does not. Less people are needed for making the same product and there is not a demand for higher quantity of that product. That is why it is rational to fire some workers. That, however, leads to another reduction in purchasing power and the economy spirals. It causes nothing less than stagnation, even a decline in living standards and unemployment, especially among the youth in southern Europe.

\section{Advantages of a Multicurrency System}

Does a multicurrency system expect weakening of the state's monopoly over money? Not necessarily. Firstly, the monopoly has already been weakened by the emancipation of central banks. Secondly, it is more and more the commercial banks that control the monetary system, not the central banks. Thirdly, nobody says that a state cannot run more currencies than one on its own. Online computer games often operate with two or more in-game currencies and all of those are managed by the developers themselves. The question for a 
multicurrency system is thus not only about the redistribution of power, as Hayek (1976) suggested, but also just of purely technical nature.

A specified hypothesis of this paper is: It is not desirable to use a single universal currency in a monetary area. The main reason is that some of the functions of money are contradictory. A maximization of money's utility for performing one function directly obstructs the maximization of another function. A typical example of this inner conflict is described by Gresham's law and involves the two most basic functions: The more a currency's value rises (e.g., because of deflation), the more are its holders motivated to store it and the less are they motivated to get rid of it, to let the money circulate. The same principle works, vice versa too. If people are expecting that their money will represent a lower value tomorrow, they are stimulated to spend it today and provide the economy with liquidity.

They can also see money as a tool designed to satisfy a general interest, to see money as a utility, a public good, or service. Or, vice versa, they can see it as a tool for satisfying individual interests. The public interest and the individual interest may be - and often are-partially or completely contradictory, of course.

Some of the functions help rather an individual (micro); some help rather the society (macro). Any new currency faces a decision what kind of a problem it should be designed to overcome. Either the main task for the currency is to ease the people their economic activities or it is to promise them some profit. (Jedlinský, 2014b, p. 2)

Separating the functions among separate parallel instruments/currencies may lower some needless tension among economic agents (public sector, households/consumers/citizens or various layers of industry, businessmen, and companies).

Beside the specific Gresham's law, there is the general Tinbergen's rule. It says that an economic policy can only be successful when the number of independent goals is to be achieved by the equal number of independent policy tools. You can surely use one currency for achieving multiple policy tools but it will most likely entail costly trade-offs.

Trying to balance one instrument (money) for achieving multiple tasks always requires trade-offs among the subsequent policies which prevent optimizing it for achieving either of the tasks or functions. That is exactly why it is not rational to expect one currency to be universal and optimal at the same time. The more people adjust it to fulfill function A, the more difficult it is to adjust it to function B.

A farmer needs a car to get him to a town. He also needs a tractor for cultivating his field. He may want to have a car that can be also used as a tractor, but that would never work, because the size of a tractor and its accessories prevents it from being fast on roads and operable in streets. A tractor also requires a different system of gear. The analogy could continue, but the point is that one instrument can appropriately fulfill multiple functions only in case they do not interfere with each other.

According to Hartmann (Cadwallader, 1984), the more functions good's attributes perform, the more valuable or better the good is. That implies that it is not possible to create a currency with an ultimate inner value, because it is not possible to adjust it in a way that would be optimal for all the desired functions at the same time.

A medieval Islamic philosopher even said that money must not have any value in itself (it may not be used for making more money), because that is the only way it can genuinely reflect value of other goods, like a clean, flat, and smooth mirror (Graeber, 2011). 
It is foolish to want from one instrument to fulfill all the functions that today's fiat currency performs. An instrument that shall work as a currency in circulation shall not be a store of value and it definitely shall not be an investment asset. An instrument that is supposed to be used for redistribution in the form of governmental transfers shall not be an investment asset. Otherwise, it causes precisely the paradox that wealth moves from the poor to the rich through the governmental indebtedness. That is not only immoral but also dysfunctional in the long run. An instrument that is volatile and has no inner value cannot store any value. A unit that is an expression of debt is not suitable for redeeming the debt. An asset whose value is largely determined by a notion of rating agencies and speculators is barely an ideal denominator of value. ${ }^{6}$ Finally, a unit of account shall be something that is stable and that is not a tool. ${ }^{7}$

There is no good reason for trying to merge these functions into one instrument. The only reason is the interest of subjects who possess the monopoly over creation of this instrument. Do states or banks try to prohibit other currencies to occur? Not really. As was written before, many new currencies appear these days, not only regional but mainly virtual and crypto. That is a challenge that the EU should stand up to. The European Central Bank (2012) published a study about virtual currencies in autumn 2012. It more or less said that virtual currencies (including crypto) are the sign of evolution. They are more of a challenge than a threat to current financial institutions and banks; there are indeed risks but these risks are rather technical. It is a task for the authorities to keep an eye on the risks. Virtual currencies allegedly represent no monetary threat for the EU.

A coexistence of multiple parallel currencies in a single monetary area is nothing new. It would be a mistake to assume that there could only be a currency of one type in a country. There are two types of Cuban peso. In antiquity, most trade was not carried in metallic money. Every wealthy Roman had fields and farmhouses. A trade denominated in grain, livestock, or slaves was usual. These are commodities that automatically grow in the system on a natural basis. Poor urban people were paid in food, lodging, etc. The tributum pacis that was allegedly paid by St. Wenceslas to Germany was not only carried in talents of silver but also in oxen. This model had barely changed throughout the Middle Ages, until the Industrial Revolution started. It was only then when the official currency finally became an instrument of everyday economic exchange for everybody.

Hayek's book (1976) Denationalization of Money has already been mentioned in this paper. In the work, he held the opinion that a currency is the only thing that shall be centrally regulated and offers an antithesis that it is exactly the currency that must not be regulated. Together with Hayek (1976), the author believes that a system of parallel currencies without a central authority is capable of providing a better economic outcome to an economy and also to mitigate the economic cycle - a disease often attributed to capitalism.

The idea of private currencies is definitely not dead or stuck in the 70's. It is for example, a financial expert and contributor to Moneyweek magazine, which speaks similarly to Hayek (1976) in his time (Keiser, 2013a). He pointed out the fact that if banks would issue their own private currencies, there would be no need to save them. Banking would be a business just as any other. Frisby pound makes a step forward from the idea of money issuing banks. Independent money does not have to be issued by banks but by basically anyone. It is up to the users which currency they decide to use - be it gold, silver, Bitcoin, Keiser dollar, or Frisby pound.

\footnotetext{
${ }^{6}$ Money can then hardly perform the information function which is one of the principal advantages of capitalism over a centrally planned economy.

7 Because of the quantity, a unit of account must be neutral; it cannot be restricted in quantity.
} 


\section{Advantages of a Single Universal Currency}

There are five basic arguments supporting the idea that a currency should be one and universal:

(1) It is simpler and more understandable;

(2) The inner pressures in a currency send price signals to the economic agents;

(3) The existence of competing currencies would hinder monetary policy of the authority;

(4) A single currency that fits in a monetary area makes the system more stable than a competition of currencies;

(5) Switching between multiple currencies is connected with conversion costs.

Is it really simpler to understand one extremely complex mechanism or is it simpler to understand several straightforward mechanisms? Is it easy to understand a control panel of a submarine? Is it difficult to understand a prepaid credit by your mobile operator, food stamps, score in a video game, or investment gold? ${ }^{8}$ Almost nobody understands all the coherence and interdependence in the complexity of modern fiat currency. It is simple only for those who want to stay in ignorance and be manipulated by financial institutions and policy makers. How many people have already noticed that money is not bound to gold? It has not been for more than 40 years.

Regarding the price of money which provides information whether it pays off to save or to spend, the ensuing actions of economic agents should bring markets back to the equilibrium. People rarely behave that (rational) way. They are more likely to behave like a crowd. Crowd behavior is mostly pro-cyclical and not anti-cyclical. Empirical studies on this subject were awarded with a Nobel Memorial Prize in economics in 2013.

More important is that the existence of multiple currencies does not eliminate this information transmission. The economic agents still have to cope with a restricted income. The agents still have to decide how they divide it between savings and spending (even though in different currencies, potentially). The information function is realized through the mutual exchange rate, similarly to this mechanism in international trade.

The monetary authority does a great job by making the currency back liquid. The note is legal tender for all debts, public and private. It is against the law to refuse state-owned money. Nobody says that a national currency must lose this privilege, when the state fosters competing currencies. As was written before, the European Central Bank as the major European monetary authority is not even hostile towards the existence of parallel currencies. European Central Banks of some countries do explicitly recognize certain private currencies, regional currencies, or even Bitcoin.

Money deliberately controlled in supply by an agency whose self-interest forced it to satisfy the wishes of the users might be the best. A money regulated to satisfy the demands of group interests is bound to be the worst possible. (Hayek, 1976, p. 31)

How can people achieve a situation where these institutions must fight for favor of money users, when they have this favor secured by law or in case they do not have to compete with anyone?

The situation of a universal currency resembles a monoculture, which is a term used in forestry. In the 19th century, Austrian-Hungarian Empire planted monocultures of spruce in Bohemia. The tree grows fast and its wood can be used for various purposes, from construction through fine furniture to paper. It seemed to be

\footnotetext{
${ }^{8}$ All these instruments may be considered money.
} 
the one and only ideal timber. The problem is that such a monoculture is vulnerable in the long run. The lack of biodiversity causes a greater vulnerability against pests and pathogens, the risk of erosion rises, nutrients are drained out of the soil which harms the water retention capacity-causing floods. ${ }^{9}$ A Chinese study proves that biodiversity not only helps to prevent disease but also improves the crop (Zhu, 2000).

There truly are conversion costs. Today, when people do not often have to choose which currency to use, such costs reach single digit percentage points. It is logical to expect what is in a multi-currency system, the costs will be pushed down by market forces. These costs can be found to be a price necessary to pay for a greater stability.

\section{An Outline of a Specific Multi-currency Monetary Setting}

This paper considers a situation in which many independent private currencies coexist with a non-credit national fiat currency. Such a solution was proposed in author's master thesis (Jedlinský, 2013). Firstly, imagine a currency issued by a firm. The currency is collateralized by the firm's production, making the currency basically a voucher. The firm can issue any amount of the currency it wants and distribute it towards its employees, trading partners, or whomever it can sell it to. Experiments with such currencies were successfully conducted after the Great Depression.

Imagine a marketplace that enables exchanging all these private voucher-currencies. Selling the currency then means exchanging it for another firm's currency. The idea resembles barter but it avoids all the problems connected to barter. Thanks to the internet and the technologies developed for cryptocurrencies, such marketplace thus became reality. It is possible for a customer to pay in a currency he or she prefers, while the seller receives another currency he or she prefers. The exchange rate is calculated according to supply and demand. The corresponding money is automatically bought on the marketplace (similar to Forex).

This mechanism already works in cryptos. Many firms already use their own virtual- or voucher-currencies. They can either develop their own aggregators (again, some firms do it, together) or adopt the already existing solutions and start their own cryptos. An example of such a marketplace is NXT monetary system or shape shift. In practice, only several currencies issued by trusted and popular firms would be probably accepted by the public. Yet, it would stabilize the financial system because money would be pegged to something specific and tangible. Without the need for systemic debt, the great advantage is that such a solution would transfer the responsibility for money issuance to the supply side of the market. It means nothing less than a practical application of Say's law. The supply would create its own demand. A general glut would become less probable.

A national currency backed by a state may in fact foster the stability of an economy based on aggregating private currencies. A national currency is an ideal unit of account of a national economy. It would seem useful, if a state regulated the duty to declare prices of supplied products in the national currency next to the private one.

It is possible that every seller could declare the exchange rate at will. What would prevent him/her to declare the prices in the national currency so high they would technically circumvent the law? The law would state that the issuer of the private currency would have a duty to repay the owner of his/her own currency in the

\footnotetext{
9 The analogy works well with spruce. Bohemian forests are damaged by the described affects till today but they are keen to return to the natural state when let alone. There are other artificial monocultures which keep the ecosystem for themselves only even though they suffer from the increased vulnerability to diseases and erosion. It is hard to say which example represents fiat currency better.
} 
national currency, in case the seller was not able to provide the product the currency stood against, for example, McDonald's issues its own currency called cheeze. Cheeze is collateralized by cheeseburgers. One cheeze is a voucher for a cheeseburger. If a customer owned more cheezes than the restaurant is ready to provide cheeseburgers, the restaurant would be obliged to repay the customer in the national currency. The more McDonald's would overrate its currency compared to the national one, the bigger debt it would create in case it would not be able to produce a number of cheeseburgers corresponding to the issued cheezes.

The system of private voucher-currencies would thus create a demand for the national currency. The national currency would stand as an anchor in the system. It would be a common currency instead of a single currency. The state could also use the currency for functions connected to public interest (investment, social security, etc.). Both systems would coexist in a symbiosis. They would mutually calm down possible monetary turbulences.

\section{Testing the Setting}

Since the findings from this paper do not always correspond to the doctrine of mainstream economics, the author believes that an experimental testing should be conducted in order to prove them. Experiment with real people and their money is immoral, thereby a simulation in a virtual economy, yet with real decision-making people as agents seems to be the right approach.

Two tests have been prepared. The first one is a massive simulation game in which players (firstly undergraduate students of economics) would play the roles of particular economic agents, including the roles of government and central bank that are entitled to setup monetary policies. Hundreds of repetitions shall be executed with different people. Data will be mined from this project and impacts of these policies (including unorthodox policies) can thus be measured on different subjects. The economy can be designed as a large economy, a middle one, or as a small opened economy. A fundraising phase of the project is now in progress.

The other test is another simulation with students. Students of several courses at the University of Economics in Prague will be merged into it. There is already a project in which students create their virtual e-shops in which virtual goods are being offered for virtual money. The new thing will be using a so-called group currency instead of the contemporary virtual currency. A group currency is a cryptocurrency concept that includes the idea of general basic income. The general basic income is the way money is issued and distributed among the members of a group. The national currency described in the last chapter can be designed in a similar way. The members will be allowed to vote for the parameters of the issue and distribution. The author of the group currency concept is collaborating on the project (Retrieved from http://groupcurrency.org/). A preparation of this project is now in progress and the testing shall begin in February 2016.

\section{Conclusions}

Monetary authorities tend to solve the growing problems connected to the currency (especially the over-indebtedness) by kicking the can down the road. Maintaining a single European currency, only because the political and economic costs of its collapse may be even bigger, is not the only solution. Europe can keep using a single currency; it can keep calling it euro. But many issues related to business cycle could be resolved or mitigated, if the model of credit based fiat currency was abandoned. The EU also needs alternative plans for the case that the current monetary system collapses independently of its will.

The paper has proved that a monetary system using just one universal currency is unsustainable in the long run. It is important to pay more attention to the research in the field of parallel currencies. A system using 
multiple parallel currencies will most likely prevail regardless of the opinions of authorities and regardless of their precedent approval. This argument is supported by the appearance of thousands of regional currencies that appeared in reaction to the Great Depression or the hundreds of cryptocurrencies that are spontaneously appearing nowadays.

Gresham's law explains the need to separate the functions of medium of exchange and store of value (treasure). Money performs many other functions beside these two basic ones. It is reasonable to expect that separate currencies will appear also for performing other functions, like:

- unit of account;

- status symbol;

- standard for redeeming debts;

- investment asset;

- instrument of government redistribution;

- stimulator in the field of externalities.

Even if there was a type of money that would be ideal for achieving all the monetary goals, it is a way more probable that such money would become dominant by proving itself in a competition with other money projects rather than by simply being defined as a single legal tender by some authority.

The theoretical findings of the paper require to be subjected to a further study and to be tested in practice. Specific tests designed to prove the findings were outlined in the paper.

\section{References}

Aziz, J. (2013). How saving endangers the economy and what to do about it. Retrieved from http://azizonomics.com/2013/11/18/how-saving-endangers-the-economy-and-what-to-do-about-it/

Bank for International Settlements. (2014). 84th BIS annual report 2013/2014. Retrieved from http://www.bis.org/publ/arpdf/ar2014e.htm

Bossone, B., \& Cattaneo, M. (2015). A parallel currency for Greece: Part I. Retrieved from http://www.voxeu.org/article/parallel-currency-greece-part-i

Buttiglione, L., Lane, P. R., Reichlin, L., \& Reinhart, V. (2014). Deleveraging, what deleveraging? The 16th Geneva report on the world economy. Retrieved from http://www.voxeu.org/article/geneva-report-global-deleveraging

Cadwallader, E. H. (1984). The continuing relevance of Nicolai Hartmann's theory of value. Journal of Value Inquiry, 18, 113-121.

Cervenka, A. (2012). Vad är pengar? Allt du velat veta om världsekonomin men inte vågat fråga om (What is money all you wanted to know about money but didn't dare to ask). Stockholm: Natur Kultur.

Clauss, A. (Director). (2009). Physische Ökonomie contra Globarisierung und Finanzen-Oder Was Sie schon immer über Wirtschaft ahnten aber nicht glauben wollen (Physical economics against globalization and finance-Or what you always knew about economy but haven't wanted to believe) [Motion Picture]. Regen: AZK_Konferenz.

Cohen-Mitchell, T. B. (1998). A brief history of money and local exchange systems. Amherst: Graduate School of the University of Massachusetts.

Dalio, R. (2012). The US economy is facing a rare set of circumstances that will be bad for markets. Retrieved from http://www.businessinsider.com/live-investors-ray-dalio-david-rubinstein-and-steve-schwarzman-at-the-dealbook-conference $-2012-12$

Eichengreen,

B.

(2013).

Restructuring

debt restructuring.

Retrieved from http://www.project-syndicate.org/commentary/barry-eichengreen-argues-that-in-international-capital-markets--the-perfect-isthe-enemy-of-the-good

European Central Bank. (2012). Virtual currency schemes. Frankfurt am Main: Eurosystem.

Fisher, I. (1933). The debt-deflation theory of great depressions. Econometrica, 1(4), 337-357.

Fukuyama, F. (1992). The end of history and the last man. New York: Free Press. 
Gesell, S. (1916). The natural economic order. Retrieved from: http://wikilivres.ca/wiki/The_Natural_Economic_Order for free Graeber, D. (2011). Debt: The first 5,000 years. New York: Melville House.

Hayek, F. A. (1976). Denationalization of money: The argument refined. London: Institute of Economic Affairs.

Hudson, M., Innes, M., \& Wray, R. (2004). Credit and state theories of money. Cheltenham: Edward Elgar.

Jedlinský, J. (2013). Currency perspectives for Europe-Water money and the private currencies aggregator (A master thesis at University of Economics in Prague).

Jedlinský, J. (2014a). What it actually means to comply with the stability and growth pact criteria? Ostravice: Slezská univerzita v Opavě.

Jedlinský, J. (2014b). What are the economic parameters of Nxt. Retrieved from http://www.nxtcommunity.org/economic-parameters-nxt

Jílek, J. (2013). Finance v globální ekonomice I a II (Finance in global economy I and II). Prague: Grada Publishing.

Keen, S. (2011). Debunking economics-The naked emperor dethroned. London: Zed Books.

Keiser, M. (2013a). Who stole from you? A robo-banker. Retrieved from http://maxkeiser.com/2013/03/02/kr413-keiser-report-who-stole-from-you-a-robo-banker/

Keiser, M. (2013b). More interest rate apartheid. Retrieved from http://www.maxkeiser.com/2013/05/more-interest-rate-apartheid/

Keiser, M. (2013c). Episode 538. Retrieved from http://rt.com/shows/keiser-report/episode-538-max-keiser-443/

Klein, M. C. (2012). Reforming macroeconomics-Claudio Borio on the financial cycle. Retrieved from http://www.economist.com/blogs/freeexchange/2012/12/reforming-macroeconomics

Krejčí, D. (1998). Teorie endogenních peněz (Theory of endogenous money). Prague: Národohospodářský ústav Josefa Hlávky.

Mandel, M., \& Tomšík, V. (2014). Dynamika úvěru v hospodářském cyklu a role makroobezřetnostní politiky (Dynamics of creidt in the business cycle and the role of macroprudential policy). Bankovnictví, 9, 1.

Mathew, J. (2014). Ecuador to create government-run digital currency as it bans bitcoin. Retrieved from http://www.ibtimes.co.uk/ecuador-create-government-run-digital-currency-it-bans-bitcoin-1458280

Mayer, T. (2014). Vollgeld: Das Geldsystem der Zukunft. Unser Weg aus der Finanzkrise ("Vollgeld”: The system of money for the future-Our way out of the financial crisis). Marburg: Tectum.

McLeay, M. E. (2014). Money creation in the modern economy. Bank of England: Quarterly bulletin. Retrieved from http://www.bankofengland.co.uk/publications/documents/quarterlybulletin/2014/qb14q1prereleasemoneycre

Minsky, H. P. (1992). The financial instability hypothesis (Working Paper No. 74, The Jerome Levy Economics Institute of Bard College, Prepared for Handbook of Radical Political Economy).

Mises, L. V. (1998). Human action-A treatise on economics. Auburn: The Luwig von Mises Institute.

Murphy, R. P. (2013). Krugman: "Fiat money...backed by men with guns". Retrieved from http://mises.ca/posts/blog/krugman-fiat-money-backed-by-men-with-guns/

Ok Turtles. (2015). Group currency. Retrieved from http://groupcurrency.org/

Phillips, R. J. (1992). The "Chicago plan" and new deal banking reform (Jerome Levy Economics Institute Working Paper No. 76, p. 164).

Samuelson, P. A. (2010). Economics. New York: McGraw-Hill Education.

Soto, J. H. (2012). Money, bank credit, and economic cycles. Auburn: The Ludwig von Mises Institute.

Suntum, U. V. (2013). A parallel currency proposal for the stronger eurostates (CAWM Discussion Paper No. 64).

Varoufakis, Y. (2012). It all began with a strange mail. Retrieved from http://blogs.valvesoftware.com/economics/it-all-began-with-a-strange-email/

WebFinance Inc. (2014). What is system? Retrieved from http://www.businessdictionary.com/definition/system.html

Zhu, Y. (2000). Genetic diversity and disease control in rice. Nature, 406, 718-722. 